\title{
Analisis Implementasi Pengukuran Suhu Tubuh Manusia dalam Pandemi Covid-19 di Indonesia
}

\author{
Unang Achlison \\ ${ }^{1}$ Universitas Sains dan Teknologi Komputer \\ Majapahit No.605 Semarang, e-mail: unang@stekom.ac.id
}

\begin{tabular}{|c|c|}
\hline ARTICLE INFO & ABSTRACT \\
\hline $\begin{array}{l}\text { Article history: } \\
\text { Received } 23 \text { October } 2020 \\
\text { Received in revised form } 02 \text { November } 2020 \\
\text { Accepted } 12 \text { December } 2020 \\
\text { Available online } 24 \text { December } 2020\end{array}$ & $\begin{array}{l}\text { The corona virus (Covid-19) has attacked almost the } \\
\text { entire world, including Indonesia. Places where } \\
\text { community activities must comply with health } \\
\text { protocols, one of which is checking human body } \\
\text { temperature. The measurement of human body } \\
\text { sensors is a very significant difference even though } \\
\text { it is applied to the same human body, this is due to } \\
\text { several factors. This research analyzes the } \\
\text { measurement results of the human body temperature } \\
\text { sensor. This study aims to determine an effective } \\
\text { and efficient human body temperature sensor. The } \\
\text { process of measuring human body temperature uses } \\
\text { a microcontroller-based temperature sensor. After } \\
\text { the results of temperature measurements using } \\
\text { different temperature sensors are obtained, the } \\
\text { measurement results are analyzed and compared to } \\
\text { obtain an effective and efficient temperature sensor. } \\
\text { Based on the analysis, the results of measuring } \\
\text { human body temperature using a thermal camera are } \\
\text { an effective and efficient sensor. } \\
\text { Keywords: micro sensor, human temperature }\end{array}$ \\
\hline
\end{tabular}

\section{Introduction}

Pandemi covid-19 menyerang Indonesia dan hampir seluruh dunia. Kasus penyebaran virus corona di Indonesia terus menunjukkan adanya peningkatan [1]. Langkah pencegahan penularan virus korona salah satunya adalah pemeriksaan suhu tubuh. Pemeriksaan suhu tubuh banyak ditemui di berbagai tempat antara lain kantor, stasiun, bandara, kafe, mall, sekolah atau kampus juga menerapkan cuci tangan dan pengecekan suhu tubuh. Suhu tubuh normal berkisar antar $36,5^{\circ} \mathrm{C}-37,5^{\circ} \mathrm{C}$ dan bila melebihi $38,5^{\circ} \mathrm{C}$ maka ada indikasi terinfeksi covid- 19 .

Pengukuran suhu telah banyak dilakukan oleh beberapa peneliti, salah satu cara terbaru memantau suhu adalah dengan menggunakan sensor inframerah [2]. Dengan menggunakan sensor ini, pengguna dapat memantau suhu dari sebuah objek dari jarak jauh.

Penelitian-penelitian terdahulu terkait pengukuran suhu tubuh manusia telah dilakukan antara lain perancangan dan realisasi alat pengukur suhu tubuh digital skala celcius dengan keluaran suara [3], alat ini dapat dimanfaatkan sebagai alternatif dalam pengukuran suhu tubuh terutama suhu tubuh manusia yang mengalami keterbatasan dalam penglihatan (tunanetra). Pengukuran terhadap suhu tubuh manusia dengan menggunakan termometer tubuh tanpa kontak fisik [4]. Rancang bangun alat pengukur suhu tubuh yang memiliki alarm pengingat jika suhu tubuh berada diatas angka $37,30^{\circ} \mathrm{C}[5]$. 
Namun dari sekian banyak rancang bangun alat yang menggunakan sensor suhu di atas, hasil ukur sensor suhu terkadang memiliki perbedaan yang sangat signifikan meskipun untuk mengukur suhu tubuh manusia hampir yang sama.

Efektifitas hasil ukur berkaitan penggunaan sensor suhu menjadi topik yang menarik untuk dilakukan analisis lebih jauh. Jenis sensor suhu menjadi penentu akurasi output pengukuran suhu yang dihasilkan. Tujuan dari penelitian ini adalah menganalisis hasil pengukuran suhu tubuh manusia sebagai variabel independen terhadap variasi jenis sensor suhu yang digunakan sebagai variabel dependen.

\section{Research Method}

\subsection{Sample Data}

Pada penelitian ini membahas tentang perbandingan nilai ukur sensor suhu tubuh manusia pada alat ukur suhu berbasis microcontroller terhadap variasi jenis sensor suhu yang digunakan yaitu sensor suhu LM35, sensor suhu infrared MLX90614 dan sensor suhu DS18B20. Penelitian ini dilakukan analisa perbandingan nilai hasil pengukuran yang dihasilkan dari variasi jenis sensor suhu yang digunakan dan akan ditetapkan mana yang lebih akurat dan efisien dalam hasil pengukuran suhu tubuh manusia.

2.2. Metode Pengumpulan Data

Metode pengumpulan data dalam penelitian melalui hasil pengukuran pada alat ukur suhu berbasis microcontroller. Blok diagram adalah suatu bagian dari prinsip dan kinerja suatu sistem dalam membuat suatu perancangan alat. Cara kerja keseluruhan sebuah alat yang akan dibuat terletak pada blok diagram system. Berikut ini merupakan gambar blok diagram dari sistem kerja pengukuran sensor tubuh manusia berbasis microcontroller.

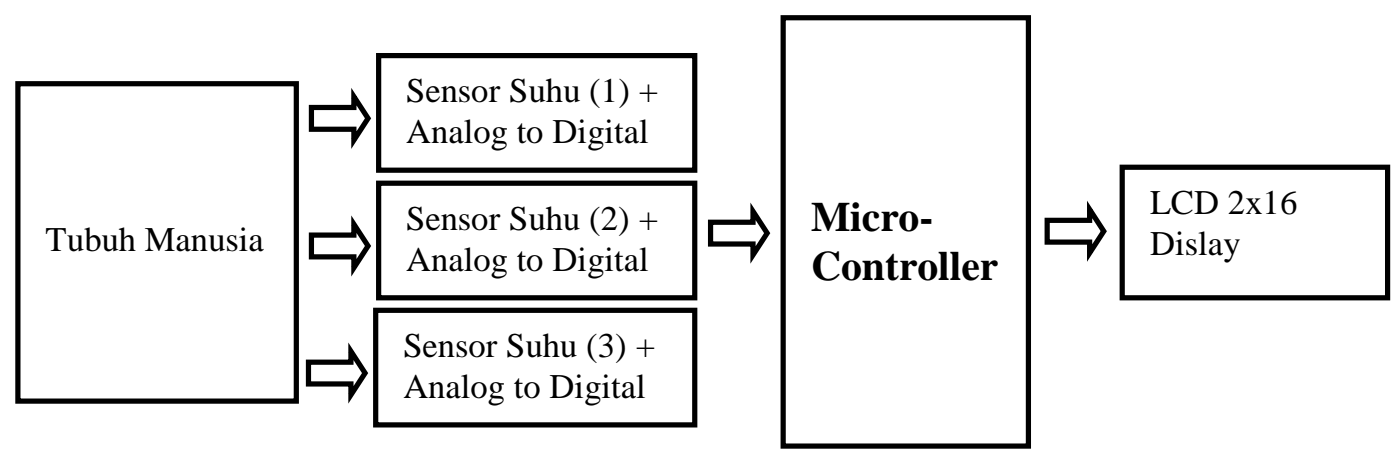

Gambar 1. Blok Diagram Sistem Kerja Pengukuran Sensor Tubuh Manusia

Berdasakan blok diagram pada gambar 1, bagian sensor suhu sebagai inputan pendeteksi suhu tubuh manusia yang akan diukur, bagian Microcontroller sebagai unit pemroses dan pengendali seluruh sistem alat. Bagian LCD sebagai penampil hasil pengukuran.

\subsection{Flowchart}

Flowchart adalah adalah alur kerja dari suatu proses terhadap sistem yang telah dibuat agar dapat dengan mudah untuk dipahami dan dijelaskan dengan simbol-simbol tertentu yang menggambarkan urutan proses secara mendetail dan hubungan antara suatu proses (instruksi) dengan proses lainnya dalam suatu program. Gambar 2 berikut merupakan Flowchart sistem kerja pengukuran sensor tubuh manusia. 


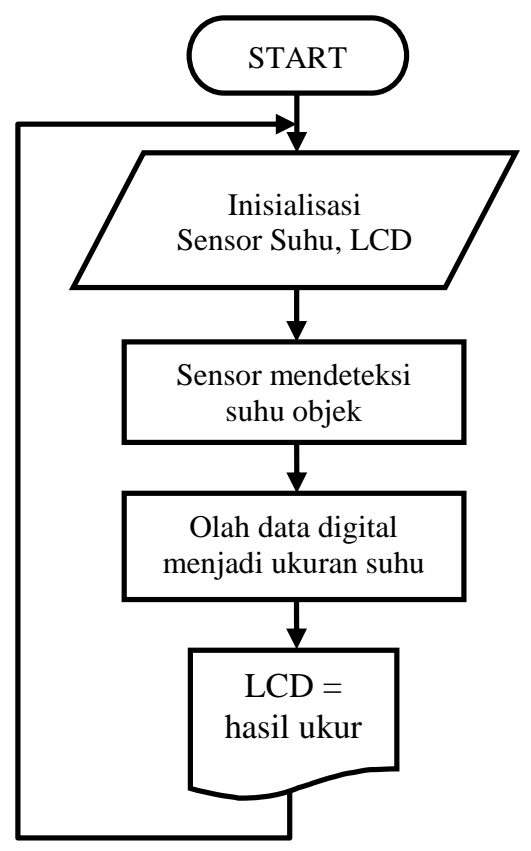

Gambar 2. Flowchart Sistem Kerja Pengukuran Sensor Tubuh Manusia

\subsection{Teknik Analisis Data}

Untuk mengetahui ketelitian pengujian suatu alat diperlukan sebuah metode perhitungan untuk mengetahuinya. Setelah diperoleh data dari hasil pengukuran suhu obyek oleh sensor suhu, maka langkah selanjutnya adalah menganalisa data tersebut untuk dilakukan perhitungan analisis nilai persentase (\%) keberhasilan dan nilai persentase (\%) kesalahan (error) [Paleri, 2015] sebagai berikut:

Persentase rata-rata hasil pengukuran sensor suhu $=(S 1+S 2+S 3) / 3 \times 100 \%$

Variabel S1, S2, S3 adalah hasil ukur sensor suhu LM35, sensor suhu infrared MLX90614 dan sensor suhu DS18B20.

\section{Results and Analysis}

3.1 Hasil Pengukuran Sensor Suhu pada Tubuh Manusia

Pengujian sistem pengukuran suhu tubuh manusia dilakukan dengan cara menggunakan sensor suhu LM35, sensor suhu infrared MLX90614 dan sensor suhu DS18B20. Suhu tubuh manusia dideteksi oleh sensor suhu menjadi tegangan, bagian Analog to Digital (ADC) untuk mengubah tegangan menjadi data digital, microcontroller mengolah data digital menjadi ukuran suhu, hasil ukur suhu ditampilkan di Liquid Crystal Display (LCD). Hasil pengujian ditunjukkan pada Tabel sebagai berikut. 
Pengujian sistem pengukuran suhu tubuh manusia menggunakan sensor suhu LM35 dan hasil pengukuran ditunjukkan pada tabel 1.

Tabel 1. Hasil Ukur Menggunakan Sensor Suhu LM35 dengan jarak $0 \mathrm{~cm}$

\begin{tabular}{ccccc}
\hline No & $\begin{array}{c}\text { Thermometer } \\
\text { standar }\left({ }^{0} \mathrm{C}\right)\end{array}$ & $\begin{array}{c}\text { Hasil Ukur } \\
\left({ }^{0} \mathrm{C}\right)\end{array}$ & $\begin{array}{c}\text { Selisih } \\
\left({ }^{0} \mathrm{C}\right)\end{array}$ & $\begin{array}{c}\text { Persentase Selisih } \\
\text { (Selisih/Nilai } \\
\text { Normal) } \times 100 \%\end{array}$ \\
\hline 1 & 30,00 & 30,00 & 0,00 & 0,00 \\
\hline 2 & 32,00 & 32,00 & 0,00 & 0,00 \\
\hline Rata-rata & 34,00 & 34,50 & 0,50 & 1,47 \\
\hline
\end{tabular}

Sumber : Alvianto Wahyu Pribadi, 2013

Berdasarkan data pada tabel 1 dapat disimpulkan bahwa persentase selisih rata-rata hasil ukur alat (simpangan) terhadap thermometer standar mencapai $+/-0,49 \%$.

Pengujian sistem pengukuran suhu tubuh manusia menggunakan sensor suhu infrared MLX90614 dan hasil pengukuran ditunjukkan pada tabel 2.

Tabel 2. Hasil Ukur Menggunakan Sensor Suhu Infrared MLX90614 jarak 2 cm

\begin{tabular}{ccccc}
\hline No & $\begin{array}{c}\text { Thermometer } \\
\text { standar }\left({ }^{0} \mathrm{C}\right)\end{array}$ & $\begin{array}{c}\text { Hasil Ukur } \\
\left({ }^{0} \mathrm{C}\right)\end{array}$ & $\begin{array}{c}\text { Selisih } \\
\left({ }^{0} \mathrm{C}\right)\end{array}$ & $\begin{array}{c}\text { Persentase Selisih } \\
(\text { Selisih/Nilai } \\
\text { Normal }) \times 100 \%\end{array}$ \\
\hline 1 & 34,50 & 34,24 & 0,26 & 0,75 \\
\hline 2 & 35,50 & 35,88 & 0,38 & 1,07 \\
\hline 3 & 36,50 & 36,54 & 0,04 & 0,11 \\
\hline Rata-rata & 35,50 & 35,55 & 0,23 & 0,64 \\
\hline
\end{tabular}

Sumber : Meilia Safitri, Gusti Arya Dinata, 2019

Berdasarkan data pada tabel 2 dapat disimpulkan bahwa persentase selisih rata-rata hasil ukur alat (simpangan) terhadap thermometer standar mencapai $+/-0,64 \%$.

Pengujian sistem pengukuran suhu tubuh manusia menggunakan sensor suhu DS18B20 dan hasil pengukuran ditunjukkan pada tabel 3 .

Tabel 3. Hasil Ukur Menggunakan Sensor Suhu DS18B20 dengan jarak $0 \mathrm{~cm}$

\begin{tabular}{ccccc}
\hline No & $\begin{array}{c}\text { Thermometer } \\
\text { standar }\left({ }^{0} \mathrm{C}\right)\end{array}$ & $\begin{array}{c}\text { Hasil Ukur } \\
\left({ }^{0} \mathrm{C}\right)\end{array}$ & $\begin{array}{c}\text { Selisih } \\
\left({ }^{0} \mathrm{C}\right)\end{array}$ & $\begin{array}{c}\text { Persentase Selisih } \\
\text { (Selisih/Nilai } \\
\text { Normal) } \times 100 \%\end{array}$ \\
\hline 1 & 36,00 & 36,50 & 0,50 & 1,39 \\
\hline 2 & 37,10 & 36,73 & 0,37 & 0,99 \\
\hline Rata-rata & 37,80 & 37,36 & 0,44 & 1,16 \\
\hline
\end{tabular}

Sumber : Rindi Wulandari, 2020

Berdasarkan data pada tabel 3 dapat disimpulkan bahwa persentase selisih hasil ukur (simpangan) terhadap nilai semestinya mencapai $+/-1,18 \%$. 
3.2 Analisis Pengujian

Berdasarkan tabel 1, tabel 2 dan tabel 3, perbedaan antara hasil ukur sensor suhu dapat disimpulkan seperi pada tabel 4.

Tabel 4. Hasil Ukur Suhu Sensor LM35, Infrared MLX90614 dan Sensor DS18B20.

\begin{tabular}{lcccc}
$\begin{array}{c}\text { Nama } \\
\text { Sensor Suhu }\end{array}$ & $\begin{array}{c}\text { Rata-rata } \\
\text { Thermometer } \\
\text { standar }\left({ }^{0} \mathrm{C}\right)\end{array}$ & $\begin{array}{c}\text { Rata-rata } \\
\text { Hasil Ukur } \\
\left({ }^{0} \mathrm{C}\right)\end{array}$ & $\begin{array}{c}\text { Rata-rata } \\
\text { Selisih } \\
\left({ }^{0} \mathrm{C}\right)\end{array}$ & $\begin{array}{c}\text { Rata-rata } \\
\text { Persentase Selisih } \\
\text { (Selisih/Nilai } \\
\text { Normal) })\end{array}$ \\
\hline LM35 & 32,00 & 32,17 & 0,17 & 0,49 \\
\hline MLX90614 & 35.50 & 35.55 & 0,23 & 0,64 \\
\hline DS18B20 & 37.00 & 36,86 & 0,44 & 1,18 \\
\hline
\end{tabular}

Berdasarkan data pada tabel 4 dapat disimpulkan bahwa persentase selisih hasil ukur sensor suhu untuk mengukur suhu badan manusia dapat menghasilkan hasil ukur yang mendekati hasil ukur Thermometer.

\section{Conclusion}

Dari hasil analisa data tersebut, maka penulis dapat menyimpulkan penelitan sebagai berikut :

a. Sensor LM35 lebih efisien dan akurat bila digunakan dengan cara ditempelkan pada dahi maupun ketiak tubuh manusia (lihat tabel 1).

b. Sensor MLX90614 lebih efisien dan akurat bila digunakan dengan berjarak $2 \mathrm{~cm}$ diarahkan pada muka maupun tangan tubuh manusia (lihat tabel 2).

\section{References}

[1] R. S. Nuroho dan dkk. (2020) . kompas.com, 2 September 2020. [Online]. Available: http://kompas.com. [Diakses 15 September 2020].

[2] Rusby, R.. (2012) . Measurement Good Practice Guide, No. 125, hal 40.

[3] Alvianto Wahyu Pribadi. (2013) "Prototipe Termometer Digital Dengan Keluaran Suara Berbasis Mikrokontroler Atmega16", Jurnal Inovasi Fisika Indonesia Vol.02 No. 03 Tahun $201311-13$

[4] Meilia Safitri, Gusti Arya Dinata. (2019) . "Non-Contact Thermometer Berbasis Infra Merah", Jurnal SIMETRIS, Vol. 10 No. 1 April 2019

[5] Rindi Wulandari. (2020) . Rancang Bangun Pengukur Suhu Tubuh Berbasis Arduino Sebagai Alat Deteksi Awal Covid-19, Prosiding SNFA (Seminar Nasional Fisika dan Aplikasinya) 2020

[6] PALERI, E. (2015). Aplikasi Sensor Load Cell Yzc-133 Sebagai Pendeteksi Berat Santan Pada Coconut Milk Auto Machine (other). Politeknik Negeri Sriwijaya. 